\title{
Karakteristik Klinik Pasien Rawat Jalan di Divisi Respirologi Bagian Anak Rumah Sakit Wahidin Sudirohusodo Makassar Tahun 2010
}

\author{
Bob Wahyudin \\ Bagian Ilmu Kesehatan Anak Fakultas Kedokteran Universitas Hasanuddin/RSU Wahidin Sudirohusodo, \\ Makassar
}

Latar belakang. Di kota Makassar, penyakit saluran napas pada anak memiliki angka morbiditas yang tinggi. Rumah Sakit Wahidin sebagai rumah sakit regional Indonesia timur juga menerima pasien rawat inap untuk pasien anak dengan penyakit saluran napas, namun belum ada laporan tentang karakteristik pasien yang dirawat jalan di Poli Khusus Respirologi.

Tujuan. Melaporkan dan menganalisis karakteristik pasien yang mendatangi Poli Rawat Jalan Khusus Respirologi Anak tahun 2010.

Metode. Metode penelitian analitik deskriptif retrospektif data sekunder status pasien rawat jalan Poliklinik Khusus Respirologi Anak

Hasil. Pada tahun 2010, 65 anak dengan penyakit pernapasan dirawat di Bangsal Respirologi Anak RS

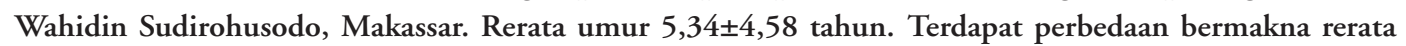
umur menurut diagnosis masuk $(\mathrm{p}=0,03)$, dan perbedaan sangat bermakna proporsi gizi buruk menurut diagnosis masuk $(\mathrm{p}=\mathbf{0 , 0 0 0})$. Tidak terdapat hubungan antara status gizi dan diameter indurasi $(\mathrm{p}=0,07)$, dan antara adanya parut BCG dan diameter indurasi tuberkulin ( $\mathrm{p}=0,97)$. Pada pasien tuberkulosis, terdapat perbedaan bermakna proporsi gizi buruk $(\mathrm{p}=0,03)$ dan sangat bermakna rerata diameter indurasi tuberkulin $(\mathrm{p}=\mathbf{0 , 0 0 0})$ apabila dibandingkan dengan pasien non-tuberkulosis.

Kesimpulan. Terdapat perbedaan umur sesuai diagnosis masuk. Pasien pneumonia cenderung berusia lebih muda, sedangkan pasien tuberkulosis cenderung berusia lebih tua. Diameter indurasi uji tuberkulin tidak dipengaruhi oleh status gizi dan ada tidaknya parut BCG. Proporsi gizi buruk dan rerata indurasi lebih besar pada penyakit tuberkulosis dibanding non tuberkulosis. Sari Pediatri 2012;14(2):84-9.

Kata kunci: karakteristik klinik, penyakit saluran napas, rawat jalan, indurasi tuberkulin

\footnotetext{
Alamat korespondensi:

Dr. Bob Wahyudin, Sp.A, IBCLC. Bagian Ilmu Kesehatan Anak Fakultas Kedokteran Universitas Hasanuddin, Jln Perintis Kemerdekaan KM 10, Makassar 90000. Telp (0411) 588442. E-mail: bob_wahyudin@ yahoo.com
}

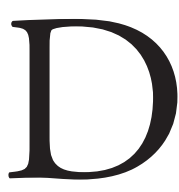
ari data Suskernas tahun 2007, didapatkan 26\% penduduk kota Makassar berada dalam kelompok umur $0-15$ tahun. Dari sepuluh penyakit utama, penyakit pernapasan menempati urutan pertama dengan 
persentase $52,7 \%$, dan menempati urutan ketujuh dari 10 penyebab utama kematian di kota Makassar. Pada balita, penyakit pernapasan khususnya pneumonia merupakan penyebab kematian utama, sebesar $22,8 \%$ (suskernas 2001). ${ }^{1}$

Rumah Sakit Wahidin Sudirohusodo adalah Rumah Sakit Regional tipe A yang berfungsi sebagai rumah sakit rujukan utama di Indonesia Timur, dengan jumlah tempat tidur 673 dan bed occupancy ratio $72,6 \%$. Sayangnya belum ada data dan analisis mengenai penyakit-penyakit anak yang mendatangi Poliklinik Rawat Jalan Khusus Respirologi Anak.

Poliklinik Khusus Respirologi Anak RS Wahidin Sudirohusodo hanya dibuka setiap hari Senin dalam seminggu. Beberapa pasien yang datang berasal dari rujukan poliklinik umum anak, sehingga jumlah kasus baru perbulan juga tidak terlalu banyak, hanya sekitar 5 sampai 10 orang perbulan.

Tujuan penelitian kami untuk melaporkan insidens (kasus baru) penyakit pernapasan yang mendatangi Poli Khusus Rawat Jalan Respirologi Anak di Rumah Sakit Wahidin. Juga dianalisis tentang hubungan beberapa faktor sosiodemografik, dan beberapa karakteristik klinik penyakit, dengan penekanan pada penyakit tuberkulosis.

\section{Metode}

Data sekunder berasal dari status rawat jalan Poliklinik Khusus Respirologi Anak RS Wahidin Sudirohusodo selama tahun 2010. Dilakukan penelitian observasional analitik secara retrospektif. Dilakukan pengumpulan data pasien antara lain umur, jenis kelamin, pekerjaan orangtua, status gizi, status imunisasi. Dalam rangka membandingkan karakteristik klinis antara penyakit tuberkulosis dan bukan tuberkulosis, dicatat juga data tentang uji tuberkulin, parut BCG, dan riwayat kontak dengan pasien TB dewasa. Status gizi dikelompokkan berdasarkan kriteria BB/TB sesuai kurva CDC tahun 2000. Diagnosis pneumonia ditegakkan secara klinik berdasarkan kriteria WHO, yaitu batuk dan nafas cepat. Rinitis akut, tonsilitis akut, faringitis akut, atau kombinasi keadaan tersebut dikelompokkan sebagai infeksi saluran pernafasan akut (ISPA) bagian atas. Didiagnosis rinitis apabila terdapat rinore. Tonsilitis apabila ditemukan pembesaran tonsil T3/T3 yang hiperemis. Faringitis apabila ditemukan hiperemis pada daerah farings. Pendekatan diagnosis tuberkulosis dilakukan dengan
TB Skor dan kemudian dievaluasi lebih lanjut secara klinis dan laboratorik. Riwayat kontak positif apabila pasien hidup serumah dengan penderita tuberkulosis dewasa, baik yang baru didiagnosis atau sedang menjalani pengobatan. Parut BCG dilihat pada lengan atas kanan. Uji Tuberkulin dilakukan dengan menyuntikkan 2TU $(0,1 \mathrm{ml})$ larutan PPD RT 23 produksi PT Biofarma Bandung, interpretasi dilakukan 48-72 jam kemudian dengan mengukur diameter indurasi dengan mistar tembus pandang. Arah pengukuran tegak lurus dengan arah penyuntikan sebelumnya, dinyatakan, dan dicatat dalam millimeter.

Analisis statistik menggunakan program SPSS 18. Data yang terkumpul dikelompokkan berdasarkan tujuan dan jenis data, kemudian dilakukan pengujian dengan analisis yang sesuai. Analisis univariat digunakan untuk deskripsi karakteristik data seperti distribusi frekuensi, rerata, dan cakupan. Analisis ini akan menjelaskan karakteristik data seperti sosioekonomi. Analisis bivariat menggunakan Uji chi square $\left(\mathrm{X}^{2}\right)$, untuk membandingkan proporsi variabel kategorik (mis: status gizi, riwayat kontak). Uji Student-t dan Anova digunakan untuk membandingkan nilai rerata dua atau lebih variabel numerik yang mempunyai distribusi dan varians normal (mis: diameter uji tuberkulin). Analisis visual dibuat menggunakan scattered plot. Kemaknaan uji statistik dinyatakan tidak bermakna apabila $p>0,05$, bermakna apabila $\mathrm{p} \leq 0,05$, dan sangat bermakna apabila $\mathrm{p}<0,01$.

\section{Hasil}

Enampuluh lima pasien dirawat di Poliklinik Khusus Respirologi Anak selama tahun 2010. Karakteristik sosiodemografik tertera pada Tabel 1. Rerata umur pasien 5,34 44,58 dengan umur termuda 0,25 dan tertua 14,60 tahun. Rerata berat lahir adalah $3040 \pm 360$,46 gram. Terbanyak beragama Islam dengan pekerjaan ayah wiraswasta. Distribusi status gizi terbanyak gizi baik, diikuti gizi kurang, buruk, dan lebih. Sebagian besar pasien telah dimunisasi lengkap (76,9\%).

Pada Gambar 1 dapat dilihat distribusi diagnosis penyakit pernafasan menurut umur dan jenis kelamin. Nampak bahwa pasien pneumonia dan ISPA cenderung mengenai anak balita, sedangkan tuberkulosis terbanyak diderita oleh anak yang lebih tua. Uji Anova menunjukkan perbedaan bermakna rerata umur di 
Tabel 1. Karakteristik sosiodemografik dan klinik

\begin{tabular}{|c|c|c|c|}
\hline Karakteristik & n (\%) & Rerata $\pm S B$ & Rentang \\
\hline Jumlah subyek & $65(100)$ & & \\
\hline Umur (tahun) & & $5,34 \pm 4,58$ & $0,25-14,16$ \\
\hline Laki-laki: perempuan & $31(47,7): 34(52,3)$ & & \\
\hline \multicolumn{4}{|l|}{ Pekerjaan ayah } \\
\hline Buruh & $10(15,4)$ & & \\
\hline Petani & $9(13,8)$ & & \\
\hline PNS & $14(21,5)$ & & \\
\hline Wiraswasta & $20(30,8)$ & & \\
\hline Pegawai swasta & $8(12,3)$ & & \\
\hline Lain-lain & $4(6,1)$ & & \\
\hline \multicolumn{4}{|l|}{ Gizi } \\
\hline Baik & $47(72,3)$ & & \\
\hline Kurang & $13(20,0)$ & & \\
\hline Buruk & $5(7,7)$ & & \\
\hline Pernapasan/menit & & $30,68 \pm 7,59$ & $25-56$ \\
\hline Nadi/menit & & $102,94 \pm 13,03$ & $80-140$ \\
\hline Suhu $\left({ }^{0} \mathrm{C}\right)$ & & $36,84 \pm 0,42$ & $36,5-38,1$ \\
\hline Leukosit $/ \mathrm{mm}^{3}$ & & $11879 \pm 5851$ & $2700-39100$ \\
\hline BB Lahir (gram) & & $3040 \pm 360,46$ & $1700-4000$ \\
\hline \multicolumn{4}{|l|}{ Status imunisasi } \\
\hline Lengkap & $50(76,9)$ & & \\
\hline Tidak/belum lengkap & $15(23,1)$ & & \\
\hline \multicolumn{4}{|l|}{ ASI sampai umur (bulan) } \\
\hline $0-6$ & $11(16,9)$ & & \\
\hline $6-12$ & $33(50,8)$ & & \\
\hline$>12$ & $20(30,8)$ & & \\
\hline Tidak pernah & $1(1,5)$ & & \\
\hline
\end{tabular}

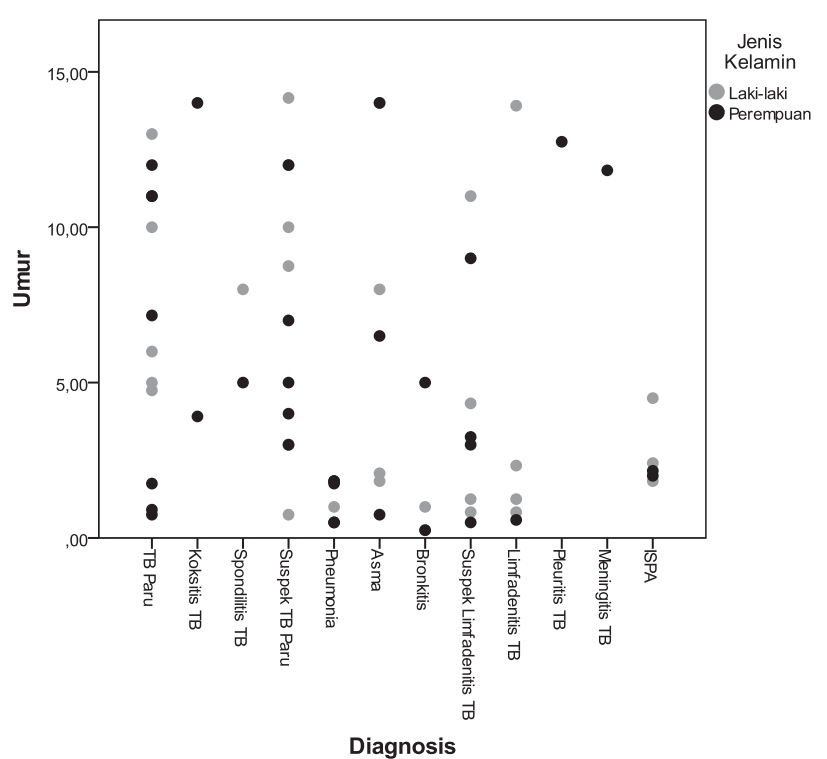

Gambar 1. Distribusi penyakit menurut umur dan jenis kelamin antara berbagai kelompok penyakit, namun analisis post-hoc untuk membedakan kelompok penyakit yang berbeda bermakna tidak dilakukan, karena beberapa kelompok penyakit mempunyai nilai 0 .

Tabel 2 memperlihatkan berbagai diagnosis penyakit pernapasan dan hubungannya dengan beberapa karakteristik klinik. Sebagian besar pasien didiagnosis dengan penyakit tuberkulosis. Apabila pasien hanya menderita ISPA, pasien tersebut tidak dirujuk ke poli khusus anak, namun apabila ada kecurigaan kearah tuberkulosis, maka residen di poli umum anak akan merujuknya. Tidak ada perbedaan bermakna antara rerata hemoglobin maupun rerata leukosit menurut kelompok penyakit, namun terdapat perbedaan bermakna dalam umur dan gizi.

Untuk mengetahui lebih lanjut karakteristik umur, gizi, parut BCG, riwayat kontak, diameter indurasi tuberkulin serta pengaruh masing-masing faktor pada penyakit tuberkulosis, maka dibuat analisis dengan mengelompokkan pasien kedalam dua kelompok 
Tabel 2. Jenis diagnosis penyakit saluran pernapasan dan hubungannya dengan beberapa karakteristik klinik

\begin{tabular}{lccccc}
\hline Diagnosis & $\mathrm{n}$ & $\begin{array}{c}\text { Rerata umur } \\
\text { (tahun) }\end{array}$ & $\begin{array}{c}\text { Gizi buruk } \\
\text { (persen) }\end{array}$ & $\begin{array}{c}\text { Rerata HB } \\
(\mathrm{mg} \%)\end{array}$ & $\begin{array}{c}\text { Rerata leukosit } \\
\text { (ribu) }\end{array}$ \\
\hline Tuberkulosis & & & & & \\
$\quad$ TB paru & 12 & 6,94 & 0 & 10,75 & 12,76 \\
$\quad$ Suspek limfadenitis TB & 8 & 4,14 & 0 & 10,48 & 14,10 \\
$\quad$ Limfadenitis TB & 5 & 3,78 & 0 & 10,64 & 10,84 \\
$\quad$ Pleuritis TB & 1 & 12,75 & 0 & 8,60 & 9,50 \\
$\quad$ Meningitis TB & 1 & 11,83 & 100 & 12,30 & 21,60 \\
$\quad$ Koksitis TB & 2 & 8,95 & 100 & 12,05 & 61,65 \\
$\quad$ Spondilitis TB & 2 & 6,50 & 50 & 10,75 & 9,67 \\
$\quad$ Suspek TB paru & 12 & 6,88 & 0 & 11,90 & 10,85 \\
ISPA & 5 & 2,58 & 0 & 9,88 & 13,12 \\
Pneumonia & 6 & 1,23 & 20 & 9,21 & 11,65 \\
Asma & 7 & 6,73 & 0 & 11,44 & 10,77 \\
Bronkitis & 4 & 1,62 & 0 & 11,42 & 12,00 \\
Total & 65 & 5,34 & 7,69 & 10,86 & 11,87 \\
\hline
\end{tabular}

${ }^{*} \mathrm{Uji}$ Oneway Anova. ${ }^{*} \mathrm{Uji} \mathrm{X}^{2}$

UJi bivariat $\mathrm{df}=11 \mathrm{p}=0,03^{*}, \mathrm{df}=11 \mathrm{p}=0,000^{*}, \mathrm{df}=11 \mathrm{P}=0,16^{*}, \mathrm{df}=11 \mathrm{P}=0,78^{*}$

Tabel 3. Perbandingan karakteristik penyakit tuberkulosis dan non tuberkulosis

\begin{tabular}{|c|c|c|c|}
\hline Parameter & Tuberkulosis & Bukan tuberkulosis & Kemaknaan \\
\hline Umur, (rerata) & $6,84 \pm 4,84$ & & \\
\hline $0-1$ & 4 & & \\
\hline$>1-4$ & 7 & & \\
\hline$>5$ & 12 & c & $\mathrm{df}=2, \mathrm{p}=0,167^{*}$ \\
\hline Rasio laki-laki:perempuan & $10: 13$ & $21: 21$ & $\mathrm{df}=1, \mathrm{p}=0,61^{*}$ \\
\hline Proporsi gizi buruk & $4 / 23$ & $1 / 42$ & $\mathrm{df}=1, \mathrm{p}=0,03^{*}$ \\
\hline Parut BCG & $19 / 23$ & $34 / 42$ & $\mathrm{df}=1, \mathrm{p}=0,86^{*}$ \\
\hline \multicolumn{4}{|l|}{ Riwayat kontak } \\
\hline Tidak ada & 3 & 5 & \multirow{5}{*}{$\mathrm{df}=4 \mathrm{P}=0,373^{\#}$} \\
\hline Tidak tahu & 5 & 9 & \\
\hline Ada & 2 & 0 & \\
\hline Diduga Ada & 1 & 4 & \\
\hline Disangkal & 12 & 24 & \\
\hline Uji tuberkulin (Rerata diameter, $\mathrm{mm}$ ) & $13,35 \pm 4,06$ & $5,14 \pm 4,69$ & $\begin{array}{l}\mathrm{p}=0,000^{\mathrm{c}} \\
95 \% \mathrm{CI}=(-10,52)-(-5,8)\end{array}$ \\
\hline
\end{tabular}

*Uji X ${ }^{2}$, ${ }^{*}$ ji Anova, ${ }^{8} \mathrm{Uji}$ t

besar; tuberkulosis dan non tuberkulosis. Apabila pasien dilabel "suspek" saja, maka pasien dimasukkan kedalam kelompok non tuberkulosis.

Tabel 3 menunjukkan pasien tuberkulosis lebih banyak pada anak di atas lima tahun, sedangkan non tuberkulosis banyak terdapat pada anak balita, meskipun perbedaan ini tidak bermakna. Distribusi jenis kelamin relatif berimbang dan tidak terdapat perbedaan bermakna dalam hal parut BCG dan riwayat kontak, namun terlihat proporsi gizi buruk secara bermakna terdapat lebih banyak pada kelompok tuberkulosis. Terdapat perbedaan bermakna di antara kelompok diameter uji tuberkulin. Telah diketahui bahwa faktor gizi bisa berpengaruh terhadap uji tuberkulin dan faktor gizi ini bisa menjadi faktor perancu hubungan antara diameter uji tuberkulin dan penyakit tuberkulosis. 
Dilakukan analisis faktor perancu untuk mengetahui apakah terdapat perbedaan gizi buruk di antara berbagai diameter uji tuberkulin. Tidak terdapat perbedaan bermakna rerata diameter tuberkulin antara pasien PEM dan non PEM. Sehingga disimpulkan bahwa memang terdapat perbedaan rerata uji tuberkulin pada pasien tuberkulosis dan non tuberkulosis, dan perbedaan tersebut bukan disebabkan oleh pengaruh faktor gizi (Tabel 4).

Faktor parut BCG juga sering dihubungkan dengan besarnya diameter uji tuberkulin. Dari penelitian kami, tidak ditemukan hubungan antara parut BCG dengan rerata diameter uji tuberkulin seperti tertera pada Tabel 5.

Tabel 5. Hubungan antara parut BCG dan diameter uji tuberkulin

\begin{tabular}{lcc}
\hline & \multicolumn{2}{c}{ Uji tuberkulin } \\
\cline { 2 - 3 } Scar BCG & $\mathrm{N}$ & Rerata diameter $(\mathrm{mm})$ \\
\hline Ada & 35 & $9,89 \pm 5,88$ \\
Tidak Ada & 8 & $10,13 \pm 6,49$ \\
\hline
\end{tabular}

Uji bivariat $\mathrm{p}=0,9.95 \% \mathrm{CI}=-4,98-4,50$

Tabel 4. Hubungan antara faktor gizi dan diameter uji tuberkulin

\begin{tabular}{lcc}
\hline & \multicolumn{2}{c}{ Uji tuberkulin } \\
\cline { 2 - 3 } Status gizi & $\mathrm{n}$ & Rerata diameter $(\mathrm{mm})$ \\
\hline Non-PEM & 39 & $9,41 \pm 5,97$ \\
PEM & 4 & $15 \pm 0,81$ \\
\hline
\end{tabular}

Uji bivariat $\mathrm{p}=0,07.95 \% \mathrm{CI}=-11,69-0,51$

\section{Pembahasan}

Penyakit saluran pernapasan, termasuk pneumonia dan tuberkulosis tetap menjadi penyebab kematian terbanyak kematian pada anak balita pada negara negara berkembang, meskipun saat ini telah dikembangkan berbagai strategi dan pedoman untuk pencegahan dan tata laksana. ${ }^{2}$

Tuberkulosis pada anak masih menjadi masalah yang sulit teratasi. Upaya untuk menentukan burden of disesase pun sulit dilakukan karena kesulitan dalam mendiagnosis penyakit ini pada anak. ${ }^{3}$ Diperkirakan insidens tuberkulosis anak bervariasi sekitar 60-600 kejadian pertahun. ${ }^{4}$

Distribusi umur di antara berbagai jenis penyakit berbeda. Pada penelitian kami, tuberkulosis lebih banyak berdampak pada usia yang lebih tua. Hal tersebut disebabkan beberapa tuberkulosis ekstra paru (9 dari 23 kasus tuberkulosis, 39\%) yaitu limfadenitis TB, koksitis TB, dan spondilitis TB. Menurut timetable Walgren, komplikasi ke tulang memerlukan waktu yang lebih lama biasanya dalam 3 tahun setelah infeksi primer. ${ }^{5} \mathrm{Hal}$ tersebut menyebabkan manifestasi klinik ditemukan pada usia yang lebih tua.

Faktor gizi konsisten mempengaruhi perjalanan penyakit pada anak, khususnya penyakit tuberkulosis. Sebaliknya penyakit tuberkulosis juga akan menyebabkan seorang anak menjadi lebih mudah terkena penyakit tuberkulosis. ${ }^{6,7}$ Defisiensi gizi meningkatkan risiko dan beratnya penyakit tuberkulosis dengan mempengaruhi fungsi imunologis, terutama imunitas selular, dengan mengurangi kinerja limfosit $\mathrm{T}$ dan sel fagosit. Infeksi TB dengan mudah menjadi penyakit TB pada anak yang menderita tuberkulosis. Pada jangka panjang, juga terjadi peningkatan risiko reaktivasi. Obat anti tuberkulosis juga akan berkurang efek farmakodinamiknya pada pasien malnutrisi. Penyakit tuberkulosis juga dapat menyebabkan malnutrisi. Pasien tuberkulosis mengalami penurunan nafsu makan, malabsorpsi protein, dan mikronutrien akan menyebabkan wasting otot dan jaringan lemak dalam jangka waktu panjang. ${ }^{7}$

Kami juga menganalisis efek status gizi terhadap diameter uji tuberkulin dan tidak didapatkan perbedaan yang bermakna. Walaupun beberapa penelitian telah menyokong hubungan antara malnutrisi dan diameter indurasi. Ganapathy $\mathrm{dkk}^{7}$ tidak menemukan hubungan antara status gizi (anthropometric) dan diameter indurasi tuberkulin, bahwa PEM antropometrik saja tidak akan terlalu menekan status imun selular. Pada pasien dengan malnutrisi yang secara klinis tampak berat (marasmus dan kwashiorkor), maka diameter uji tuberkulin akan terpengaruh.

Scar BCG merupakan salah satu indikator seorang anak telah divaksinasi BCG atau tidak. Bozaykut $\mathrm{dkk}^{9}$ menemukan hubungan yang bermakna antara keberadaan parut BCG dgn diameter uji tuberkulin (tidak ada parut vs ada parut BCG; $2.8 \pm 2,6$ vs 6,1 $\pm 5,1$ ), dengan rerata umur $3,3 \pm 1,7$. Bozaykut juga menemukan bahwa pada kelompok umur yang semakin tinggi, kemaknaan hubungan parut dan uji tuberkulin juga semakin berkurang. Hal tersebut karena respons imun yang lemah akibat vaksinasi BCG seiring umur yang semakin meningkat. Pada penelitian 
kami, rerata umur pasien lebih tinggi $(5,34 \pm 4,58)$ tidak terdapat perbedaan bermakna antara parut BCG dan diameter indurasi tuberkulin.

Penelitian dengan mengandalkan data sekunder dari rekam medik Rumah Sakit, berpeluang mendapatkan data yang kurang terpercaya. Jumlah pasien yang kurang juga berpeluang dalam menimbulkan bias analisis. Disarankan dimasa depan untuk membuat sistem rekam medik yang lebih baik sehingga dapat mencatat berbagai aspek perjalanan penyakit beserta hasil radiologik dan laboratorium.

\section{Daftar pustaka}

1. Pemerintah Kota Makassar. Profil kesehatan Kota Makassar Tahun 2007. Makassar: Pemerintah Kota Makassar; 2007.

2. Black RE, Cousens S, Johnson HL. Global, regional and national causes of child mortality in 2008: a systematic analysis. Lancet 2010; 375: 1969-87.

3. Starke JR. Childhood tuberkulosis. A diagnostic dilemma. Chest 1993;104;329-30.

4. Newton SM, Brent AJ, Anderson S. Paediatric tuberkulosis. Lancet Infect Dis. 2008; 8: 498-51.

5. Miller FJW. Tuberkulosis in children. Edinburgh: Churchill Livingstone; 1982. h. 144-55.

6. Gupta BK, Gupta R, Atreja A. Tuberkulosis and nutrition. Lung India 2009;26:9-16.

7. Nutrition Information Centre University of Stellenbosch. Tuberkulosis (TB) and nutrition. Diunduh dari: http:// www.sun.ac.za/nicus/. Di akses tamggal 10 Juni 2011.

8. Ganapathy T, Chakraborty AK. Does malnutrition affect tuberkulin hypersensitivity reaction in the community. Indian J Pediat 1982;49:377-82.

9. Bozaykut A, Ipek OA Ozkars MY. Effect of BCG vaccine on tuberkulin skin tests in 1-6-year-old children. Acta Pediatr 2002;91:235-8. 